\title{
EATURES OF IMPROVEMENT OF COST ACCOUNTING METHODS AND PRODUCT ACCOUNTING CALCULATION
}

\author{
Ribalko O.M., Varlamova I.S., Yevtushenko R.M. \\ Zaporizhia National University \\ Ukraine, 69063, Zaporozhye, 66 Zhukovsky Street \\ Irina.varlamova.zp@gmail.com \\ ORCID 0000-0003-0757-1730, ORCID 0000-0002-9921-327
}

Key words:

planning, cost, enterprise, methods, costs, target costing, classification, resources, efficiency, optimization.
The article analyzes traditional and modern methods of cost planning. The classification of production costs using the method of determining the elements that make up the cost of production. It is substantiated that the expediency of using each of the methods depends on a number of factors, namely: the peculiarities of the enterprise: the nature of the production process, type of product, the level of complexity of the production process, achieved results and market conditions. Among the traditional ones, the following methods are singled out and characterized: the method of cost planning by technical and economic characteristics, estimate, calculation method, normative. Among the modern planning methods, the focus is on the following: out-of-order method of calculating the cost of production, preliminary (post-process), the method of coverage and target costing. Target costing is singled out as a method of calculating the cost of production, which allows a new look at the interdependence of price, profit and cost. It is determined that with the introduction of target costing there may be some difficulties: in the development of a new product should involve departments; the actual cost may suddenly exceed the target already in the production process; it is not necessary to change the technology of production of a new product just to reduce its cost.

\section{ОСОБЛИВОСТІ УДОСКОНАЛЕННЯ МЕТОДІВ ОБЛІКУ ВИТРАТ ТА КАЛЬКУЛЮВАННЯ ОБЛІКУ ПРОДУКЦІЇ}

\author{
Рибалко О.М., Варламова I.С., Евтушенко Р.М. \\ Запорізький національний університет \\ Україна, 69063, м. Запоріжжя, вул. Жуковського, 66
}

\begin{abstract}
Ключові слова:
планування, собівартість, підприємство, методи, витрати, таргет-костінг, класифікація, ресурси, ефективність, оптимізація.
\end{abstract}

У статті проаналізовано традиційні та сучасні методи планування собівартості. Здійснено класифікацію витрат виробництва з метод визначення елементів, котрі складають собівартість продукції. Обгрунтовано, що доцільність використання кожного з методів залежить від низки чинників, а саме: особливостей діяльності підприємства: характер виробничого процесу, вид продукції, рівень складності виробничого процесу, досягнуті результати та кон'юнктури ринку. Серед традиційних виокремлено та охарактеризовано такі методи: метод планування витрат за техніко-економічними характеристиками, кошторисний, метод калькуляції, нормативний. Серед сучасних методів планування зосереджено увагу на таких: позамовний спосіб калькулювання собівартості продукції, попередільний (попроцесний), метод величин покриття та таргет-костінг. Виокремлено таргет-костінг - як метод калькулювання собівартості продукції, що дозволяє по-новому поглянути на взаємозалежність ціни, прибутку і собівартості. Визначено, що за умови впровадження таргет-костінгу можуть виникнути певні труднощі: в розробці нового продукту повинні брати участь підрозділи; фактична собівартість може несподівано перевищити цільову вже в процесі виробництва; не варто змінювати технологію виробництва нового продукту тільки для того, щоб знизити його собівартість. 


\section{Statement of the problem}

In the economic literature, much attention is paid to the definition of "cost", "cost" in determining the method of accounting for production costs or methods of calculating the cost of production. The article considers the essence of these concepts and analyzes the ways to reduce them, as well as clarify the meaning of the terms "cost", "cost" when calculating the cost of the enterprise engaged in the production of various products.

\section{Analysis of recent research and publications}

Both foreign and domestic scientists study the cost of production. It should be noted that many practitioners and scholars by this term mean a set of direct and indirect costs, not considering the cost as an indicator of the effectiveness of financial and economic activities. Definition of "cost" as the cost of resources used in the production and sale of products (services), supported by economists Atkinson Anthony A., Starodubtseva E.B., Vakhrushina M.A., Kamenitser S., Kaplan Robert S., Karpova T.P., Komissarova I.P., Kondrakov N.M., Lozovsky L.Sh., Reisberg B.A. Ways to reduce costs are considered by scientists Shegda A.V., Bilukha M.T., Boychik I., Butynets F.F., Pokropivny M.G. The choice of costing method depending on the industry is considered by I.V. Kobishtan.

\section{Statement of the problem}

Review and analyze the components of the cost, as well as the process of creating a cost management system (planning, accounting, analysis, reduction measures) in order to reduce cost items by increasing cost efficiency.

\section{Objectives of the article}

Production costs and cost of production - one of the most important financial indicators of the enterprise. Today, they are the basis for finding many other financial indicators.

Effective management of the enterprise, in modern conditions, in many cases depends on the quality of decisions made by the management on the optimal allocation and use of company resources. Also, the ability to spend resources sparingly and maximize the return on them is the basis of cost management of the enterprise and affects the amount of profit and profitability.

UAS 16 "Costs" determines the structure and composition of costs in accounting. The costs corresponding to the reduction of assets include the value of all tangible assets that were used in the manufacture of products, for the repair of non-current assets, for administrative and socio-cultural purposes; the value of sold current tangible assets; residual value of liquidated (written off) assets, lack of inventories, etc. Expenses that increase liabilities include: accrual of: wages, taxes, fees and mandatory payments; deductions for compulsory and voluntary insurance; rent, etc.

Depending on the method of allocation to the objects of accounting costs are divided into direct, which can be attributed directly to the creation of a particular type of product or service, and indirect, which are common to several types of products or services or related to management and sales functions in the enterprise.
The essence of indirect costs is that at the time of their occurrence it is impossible or even inappropriate to relate to a single product, so such costs are distributed through selected distribution bases.

Depending on the connection with the technological process of production costs are divided into basic, directly caused by the technological process of production - wages of key production workers; the value written off in the production of stocks; depreciation of production noncurrent assets, etc., and invoices, which are relatively constant over time, because they almost do not change when changing the volume of activity - administrative, management, marketing costs.

Depending on the change in the volume of activity costs are divided into variables that change in direct proportion to changes in the volume of activity and constants that do not depend on the volume of output.

There are the following methods of cost accounting in relation to the technological process of production:

- process method, which represents the production process as separate stages or processes in which the raw material undergoes a single technological process with a short production cycle; the method is used in large-scale production, mining, construction materials;

- preliminary method, which is characterized by processing at each redistribution of the semi-finished product, except the first where the raw material is processed, is used in large-scale production, in the manufacture of chemical, textile, metallurgical, sausage, canned products;

- out-of-order method, for which costs are grouped for each order separately for the period of execution of this order, which may not coincide with the reporting period, is used for single, aircraft, machine, shipbuilding, various areas of service;

- postoperative method, which combines out-of-order and post-process methods, where production takes place in batches with distinctive features; used in the garment, footwear, automotive industries;

- production method, which is a kind of out-of-order method, but the costs are grouped by time periods and products, and the cost is calculated as the average value of the calculation per unit of product; used in the garment and chemical industries.

In practice, very often used mixed cost accounting methods that combine the features of several of the above methods. The most effective and promising method, scientists recognize the hybrid method based on postoperative. There is not yet fully resolved the issue of separation of cost accounting methods and calculation methods, which is solved through the transformation of technological and organizational conditions of production, based on changes in ownership. Such combined classifications of cost accounting and calculation are based on two different features at the same time: control of production costs and grouping by objects of accounting. Since there is no single classification criterion, this leads to the fact that some cost classifications are based on the principles of accounting for production costs, and in others - the calculation of the cost per unit of output. The basis of cost accounting classifications should be 
the ways in which information is accumulated, not the type of products or facilities in which that information is accumulated. Businesses can use different calculation methods. So IV Kobyshchan believes that the choice of calculation method is determined by several factors:

1) industry features;

2) organizational features, namely the scale of the enterprise, the method of selected cost control.

According to the criterion of efficiency of accounting, calculation methods in our country are divided into two main types - normative and actual. The normative method involves accounting for actual costs in terms of elements of norms and deviations, identifying savings or overspending. It is most often used in manufacturing industries with mass and serial production of various and complex products. This method of calculation, in contrast to the clear actual, has the main advantage that it allows you to control costs by comparing the calculation of normative and actual values, respond quickly and take action at the stage of production, rather than after the end of the period. However, the main disadvantage is the high labor costs in the organization of accounting within the norms of costs and deviations from them. There are other methods of calculation, which are widely used in enterprises of various industries around the world, which are still being used in domestic enterprises due to the raw material orientation of the Ukrainian economy and the lack of regulatory application. Among them are the following methods:

1) Standard-costing - a partial analogue of the domestic normative method of calculation, which has the ability to quickly control costs, but complicates the process of price formation, as it is not related to the sale of products (services).

2) Direct costing - the method divides costs into fixed and variable. The cost is taken into account only in part of the variable costs, and constants are written off directly to reduce the company's profit. 3) The system "Exactly on time", characteristic of artificial production, which allows to reduce the level of stocks, increase the reliability of orders, reduce the risks of obsolescence of products.

4) ABC-costing allows you to make a calculation most accurately by allocating overhead costs for a particular product, to establish a close relationship between the information obtained and the process of cost formation, but requires increased costs associated with management.

5) Benchmarking - a comprehensive assessment of cost management in the enterprise in comparison with the benchmark company, which allows you to optimize cost management based on the experience and technology of other organizations, but the wrong choice of benchmark will reduce efficiency;

6) Life cycle costing (LCC) - is to determine the total cost of the product, namely its life cycle, from its design to decommissioning. The advantages of this method include the ability to assess in the long run the costs incurred and cover them with appropriate income, accurate cost forecasting, comparing the cost structure and income structure. However, there are no periods of financial results, overheads are not taken into account, so the information provided by this method is not comprehensive, and if you add overhead, the information becomes more likely.
7) Target-costing - the method is to determine the cost of pre-pricing and subtracting the planned profit. Thus, the target costs for new products are set, and the ability to control at the stage of product development (services), but there is a possibility to face the impossibility to reduce costs due to the technical capabilities of the enterprise, and requires a lot of time.

8) Kaizen-costing - is a continuation of the method of target-costing, but the achievement of the estimated cost is already at the stage of production with the involvement of all personnel, which allows you to continuously reduce costs and keep them at a given level. However, such a method requires the motivation of workers.

9) Cost-peeling - achieving maximum and rapid cost reduction, used in crisis management and increasing competitiveness. However, requires staff reductions, is suitable for individual costs or units and only for a certain period of time.

The considered methods of cost accounting and calculation methods are used in various enterprises around the world. Each of these methods has its own specifics, weaknesses and strengths, scope. That is why the company must analyze its processes in detail, define management tasks, clarify the objects of cost management.

The choice of the optimal method of calculation contributes to the adoption of effective management decisions at different levels of management of the organization. To date, the share of organizations that use only one method of calculating costs without combining it with another has decreased significantly. The above methods have found practical application in various combinations. For example, use the out-of-order method when calculating the incomplete cost of orders; combines preliminary calculation and use of norms of expenses of stocks and thus to consider also their actual expenses. It is important that the chosen method or combination of methods provides the ability to group costs by objects of accounting, the main task of timely control of production costs, cost management by variance and profit.

Therefore, based on the classification of costing methods and the classification of cost accounting methods, the answer to the question of the relationship of these two concepts - the need to distinguish them as separate objects for research. First of all, cost accounting and calculation strive for different purposes. Thus, the main purpose of cost accounting is the use of various techniques for recording costs, summarizing, generalizing, referring them to accounting registers, a set of techniques for documenting business transactions, reflecting production costs, which should ensure the formation of the actual cost of production. At the same time, calculation methods are a tool for cost analysis, control of their formation. That is why in the management accounting the main place is occupied by construction of actual calculations of prime cost of production (services). It should be noted that the Law of Ukraine "On Accounting and Financial Reporting in Ukraine" recognizes the actual cost as one of the main principles of accounting and financial reporting, ie the most important component is the valuation of enterprise assets based on costs of production (services) and inventories. 
Regarding the meaning of the term "Cost" most thoroughly reflects the essence of VM Parkhomenko - is a reflection of the costs in value terms associated with the use in the technological process in the production of products (services) of" natural resources, raw materials, fuel, energy, fixed assets, intangible assets, specialized equipment, tools, equipment, labor and financial resources, as well as the total cost of the production process and sale of finished products, mandatory deductions set by the state.

Based on p11 P (S) BU16 industrial enterprise forms a list and content of costing items and guided by the Guidelines for calculating the cost of products (services) in industry, uses the following recommended costing items for costs incurred:

1. "Raw materials", which includes the value of these stocks, from which the products are made and can be directly attributed to its manufacture or is an important part of the manufacture of products (services). In some industries, this cost item may be more detailed. For example, fuel should be allocated separately for testing, for example, aircraft, or costs related to mineral exploration.

2. "Purchasing semi-finished products", which includes all purchased semi-finished products, which are to be installed in the product or finished at the enterprise according to the normal course of the technological cycle, as well as those that can be used for packaging finished products.

3. "Purchasing components" take into account the cost of purchased units, products for the assembly of prefabricated units of products to be installed unchanged in the production process (services).

4. "Services of third parties" - are certain works that are related to the technological process of manufacturing products (services), performed by contractors or subsidiary units of the enterprise, not related to the main activity, but directly related to the product (service) produced .

5. "Fuel and energy for technological purposes" - are necessary to ensure the technological process of the cost of all types of fuel and energy, both self-manufactured and purchased from third parties.

6. "Return waste", which includes the cost of returned waste generated during the manufacture of products (services), and deducted from the article "Raw materials".

7. "Basic wages of production workers" are the costs of payment of basic wages to workers in accordance with established labor standards (time norms, production, maintenance, job responsibilities), engaged in the production of products (services), and which is calculated according to the accepted at the enterprise systems of payment of work in the form of tariff grids (salaries), piece rates for the workers engaged in production and official salaries for employees.

8. "Additional wages", includes the cost of additional production staff of the enterprise engaged in the production of products (services) depending on the results of economic activity of the enterprise, additional wages charged for overtime work, for labor achievements and ingenuity, for special working conditions. Surcharges, allowances, guarantee and compensation payments provided by law, bonuses related to the performance of production tasks and functions are taken into account.
9. "Deductions for social insurance" are the amounts of deductions from the basic and additional wages and, in general, is $22 \%$, according to the Law of Ukraine "On the collection and accounting of a single contribution to the obligatory state social insurance” №2464-VI from 08.07.2010.

10. "Costs for maintenance and operation of equipment" - an article that includes depreciation of machinery, equipment and vehicles for complete restoration, operating costs of equipment and all types of repairs, except for modernization, in-house movement of goods, wear of low-value and perishable tools and devices, payments for compulsory insurance, as well as salaries of support staff associated with the maintenance and operation of equipment, etc.

11. "General production costs" - an article that combines all the costs of organizing the production process and its management: wages of shop management, their travel expenses, rent for the use of general production funds, depreciation of own production assets, costs to improve production, utilities shop costs, labor training costs, etc.

12. "Costs due to unavoidable defects" include the cost of unusable raw materials or semi-finished products due to adjustment of equipment or other technical reasons, or the cost of eliminating such defects, as well as the cost of broken products during production.

13. "Related products" (deducted) are those products of proper quality and suitable for further sale, obtained simultaneously with the main product in the same process, but for him the calculation is not made separately, and the cost is set at a certain price.

14. "Other production costs" are the costs of testing the quality of products (services) for compliance with established standards, regulatory requirements.

The above calculation points are included in the production cost of products (services), but there are other costs that form the price of products together with profits, these are:

15. "Administrative costs" - are the costs associated with the management of the enterprise, salaries and maintenance costs of management staff, their business trips, maintenance and maintenance of fire and security guards, payments for emissions and discharges of pollutants, waste disposal in the environment natural environment, training of administrative staff, transportation costs for workers, interest costs on financial loans, taxes, deductions, consulting services, entertainment expenses, etc.

16. "Sales costs" include the cost of maintaining warehouses, wages of staff engaged in sales, loading, unloading, packaging, transport and insurance costs of the supplier, which are included in the price of products, the cost of export (export) duties and customs duties, for advertising and pre-sale preparation of products (services).

17. "Other operating expenses" are related to research, maintenance of socio-cultural facilities, fines, penalties, penalties, the amount of bad debts.

The main purpose of accounting and research of production cost calculations:

1. Determination of reliable actual costs in full and timely submission of information relating to the production of a particular product (service) or batch of products. 
2. Ability to calculate the actual cost of all products or individual units.

3. To control the use of resources, such as stocks, labor resources, analysis of the involvement of third-party organizations in the production of products.

The use of the cost indicator in the management of the enterprise requires the classification of this indicator according to certain characteristics that can be used to assess the activities of the enterprise. For example, Professor FF Butynets proposed the following classification:

- technological cost, which consists of direct costs at the workplace or site during the passage of certain technological operations, the manufacture of parts, assemblies, etc.;

- production cost, which differs from the technological in the amount of costs associated with the management of production units;

- marginal (limited) cost, including direct variable costs, which are attributed to each unit of production;

- factory cost, which combines production costs with administrative and other operating costs;

- full cost, which includes in addition to production costs, distributed administrative costs, anddistributed marketing costs.

- individual cost, which characterizes the costs of an individual enterprise for the manufacture and sale of products;

- corporate cost, which includes production costs and costs of selling products for the association of enterprises;

- average industry cost - characterizes the average industry costs for the production of a particular product;

- planned cost, which is calculated at the maximum possible cost of production provided for in the plan for the next period;

- the actual cost, which includes all costs for the manufacture and sale of products.Planned, production, actual and full cost are distinguished depending on the need for their use. Planned - sets the costs expected for the period of manufacture and sale of new or improved products, taking into account technical features. Production - records direct costs and general management, excluding non-production costs. Actual - in addition to the production cost takes into account losses from force majeure (natural disasters, manmade disasters) fines, penalties, penalties and more. The full cost, in addition to production costs, also takes into account administrative costs, marketing and sales costs.

Therefore, given all the above, a reliable definition of cost is extremely important, because the more perfect the organization of accounting, combination of calculation methods and techniques used, the easier it is to identify reserves to reduce the cost of production through analysis. Reducing the cost allows you to reduce the price of products sold, which, in turn, helps to minimize costs in those industries where these products are used.

The cost is closely related to the efficiency of production and in order for the company to successfully and significantly achieve its main goal - to make a profit, financial managers need to take into account this relationship. Cost management is carried out in a cyclic sequence:
1. Formulation of goals to be achieved in the application of cost management.

2. Organization of the process: classification of costs, determination of cost accounting methods and costing method, appointment of costs responsible for each item and development of motivation schemes, introduction of cost reduction tools.

3. Planning: the mechanism of cost formation and evaluation of their optimality.

4. Control: cost accounting system and analysis of deviations.

5. Coordination: a mechanism for making changes and adjustments to the cost management system. During the analysis, a management mechanism is chosen - regular monitoring with periodic search for reserves, or emergency search for other suppliers of raw materials, or aggressive promotion, or reorganization of the enterprise structure, etc.

According to experts, it is necessary to manage costs and production costs in order to: - to know reliably where, when, at what stage and in what quantity the stocks of the enterprise are spent, resources are consumed; - forecast the time and volume of needs for additional financial resources; - ensure the maximum possible level of return on assets that are already available;

- to produce competitive products at the expense of lower costs and, accordingly, prices for these products;

- maximize and guarantee profits in the short and long term.

Cost management is based on the management of functional qualities of products, technologies and technological parameters, parameters of resource equipment, processes, procedures, organizational structure, etc. Thus, the purpose of cost management is not only to reduce the same cost, but to increase cost efficiency, increase the efficiency of each cost increase, to prevent inefficient costs.

The management accounting system, which is the most important source of information about the internal environment of the enterprise, is aimed mainly at providing accurate and up-to-date data on the cost of production, the cost of customer service, the cost of orders, contracts. Comparing the cost with the price, you can estimate the profitability of certain products, customers, etc. Scientist Grabovetsky BE in his work notes the following main tasks of cost analysis and cost of production: monitoring the intensity of planned tasks; control of the degree of implementation of the plan (government orders, contracts, agreements), composition, product quality, rhythm and uniformity of production; finding factors of deviation from the plan and level of previous periods; finding reserves to increase production and sales, improve product quality, ensure the rhythm and uniformity of production; conducting market monitoring.

The cost is affected by all aspects of the enterprise:

- quality of technological equipment of production;

- the level of organization of production and labor,

- the degree of involvement of production capacity;

- cost-effectiveness of stocks and labor resources and other conditions and factors that characterize the production and economic activities. 
In practice, the most common factors to increase the net profit of the organization are: - increasing the volume of products (services) produced or expanding the range of goods; - increase in product prices; - or reduce prices for their products, which allows you to increase product competitiveness and significantly increase sales if demand allows; - reduction of production costs, ie reduction of the cost of production.

The last point is the source of application of various ideas, innovations and a field for application of a number of approaches and methods, experimentation. To achieve significant results in reducing costs, first of all, it is necessary to study the structure of the enterprise and derive optimal ways to reduce the cost of production without compromising the possibility of obtaining the maximum possible income.

The organization that creates the product of consumption in a particular industry, you need to analyze and make a plan to reduce costs at the expense of each type of cost. You can make it using the following options:

- determine the desired percentage reduction of all costs and unit costs;

- make a list of actions and measures that will allow budget savings. Appoint those responsible for the implementation of each item and set deadlines;

- establish and calculate the effect that the organization plans to obtain from the implementation of each item in cash.

To determine the impact on the cost, its degree, and grouping of factors, are analyzed in detail for each item of costing. The obtained actual results are compared with the results of previous periods or with planned indicators. Differences and deviations are the subject of factor analysis, which has recently become a popular tool in enterprise management, and occupies a special place in cost planning. The essence of factor or functional-cost analysis of costs for production and sale of products is to find and determine excess costs at any stage of production (services). Scientific and technological progress does not stand still, which creates the conditions under which the need for past costs, over time, decreases or becomes unnecessary. The result of such an analysis is a reduction in unit costs with the maximum allowable reduction of technical parameters of products to their functionally minimum level. The object of analysis is not only the product as a whole (service), but also its components, as well as technological processes of production and labor organization. If you consider the costs of the costing items, then for each item you can identify your own ways to reduce costs. So for the first articles "Raw materials", "Purchasing semi-finished products", "Purchasing components" by reducing the rate is the rejection of expensive materials, semi-finished products, units in favor of cheaper counterparts, as well as reducing the cost of materials. You can also review the terms of supply agreements with third-party organizations or contractors that provide production services and are included in the cost item "Third-party services". And also to consider a possibility of expediency of independent manufacturing of necessary stocks, or independent performance of those services for which third-party organizations were involved earlier. Regarding the item of expenditure "Basic wages of production workers", it should be noted that a significant role is played by increasing labor productivity, which means reducing labor costs per unit of output, which, in turn, reduces the share of wages in the structure cost. The most important indicator is the introduction into production of the results of scientific and technological progress.

Improvements in technology, the use of the latest equipment, the transition to automation and mechanization of the production process significantly minimize costs. It is resource-saving, resource-saving technologies - this is the way out for Ukrainian producers, which will also save in the article of costs "Fuel and energy for technological purposes."

Slightly reduce the item of expenditure "Social security contributions" allows you to attract workers with disabilities. SSC is set at $8.41 \%$ of the amount of salary accrued to each insured person by types of payments, which include basic and additional salary, other incentive and compensation payments, including in kind, determined in accordance with the Law on Remuneration of Persons with Disabilities.

The item "Equipment maintenance and operation costs" can be reduced by reducing the cost of maintenance and repair of equipment. For example, to control the allocation of additional funds, which can lead to an increase in the balance of spare parts. it is necessary to plan works competently as timely and regular repair will provide safety of equipment, does not demand big efforts and expenses, and the main thing will help to exclude large-scale works in case of serious breakdowns. Also, some of the work can be transferred from contractors to their own repair crews. It is also necessary to analyze the equipment that is not used. What can be dismantled, while posting useful parts, and unused fixed assets to sell.

Thanks to the consolidation of the enterprise and cooperation, you can also reduce costs. By expanding production and increasing the range of products, you can achieve cost reduction. Due to this, production volumes increase, and the price of this product decreases. It can be useful to integrate production with partners, handing them part of the process. Also, the item "Overhead costs" can be reduced by paying rent by buying the premises from the owner or subleasing part of the area.The largest share also includes wages of non-core production workers, expenses for household needs, maintenance of buildings and structures of non-production nature. Therefore, it is necessary to analyze the need and degree of retention of each component, as well as to consider the possibility of combining related shops or sites for large-scale production in order to reduce the management of the shop.

Significant reserves for cost reduction are concluded in the reduction of losses from marriage. The reason for this may be, as if the equipment is not working properly, and the human factor or dishonest performance of staff duties.

Consider ways to reduce "Administrative costs". Competent reorganization of administrative staff, reduction of redundant services and their functions, respectively materials, equipment for their maintenance, can significantly reduce the percentage of costs under this article. Most administrative departments use up to $20 \%$ of 
their budgets to control and coordinate their own activities. It is also necessary to analyze which departments perform the same work in parallel with each other, to reduce the input and processing of data manually, to give preference to the use of IT resources.

It is possible to save on sales costs by strengthening labor discipline, rhythm and uniformity of production, adherence to contractual discipline, adherence to the main principles of rational and efficient allocation of productive forces, namely reducing the path between raw materials and production, between producer and place of sale. The decisive condition for reducing costs is a strict regime of savings in all areas of economic activity of the enterprise and rational use of raw materials. Even small savings of materials, raw materials, energy or fuel in the production of each unit of production has a significant effect.

From the point of view of social positions, reducing the cost and increasing the company's profit is the emergence of opportunities for material incentives for workers, solving social problems of the company, as well as investing in social projects, including for the benefit of employees, ie the concept of corporate social responsibility.

\section{Conclusions}

The most important indicator of the enterprise - cost, characterizes the degree of use of all resources, the more intensive, the more efficient the enterprise, the lower the cost of production, which in turn allows you to maximize profits. It is impossible to equate the concept of cost and cost, as well as cost accounting methods and costing methods, because costs are a structural unit of cost, and the latter should be understood as an important economic category. Cost management, which includes planning, analysis, accounting, allows to increase the efficiency of management, guarantees the possibility of development and competitiveness of the enterprise in the market.

\section{References}

1. Kobishtan IV Methods of accounting for production costs and methods of calculating the cost // Economic Analysis: Theory and Practice 2004 № 13 (28) P. 56-61.

2. Law of Ukraine "On Accounting and Financial Reporting in Ukraine” dated 16.07.1999 № 996-XIV [Electronic resource]. Access mode: http://zakon4.rada.gov.ua/laws/show/996-14.

3. Regulation (standard) of accounting 16 "Costs". Approved by the order of the Ministry of Finance of Ukraine № 304 dated November 30, 2000.

4. Butynets FF Organization of accounting / F.F. Butynets, S.M. Oliynyk, M.M. Shigun. Zhytomyr : PE "Ruta". 2002. $591 \mathrm{p}$.

5. Grabovetsky BE Economic analysis / B.Ye. Grabovetsky. Куiv : Центр учбової літератури, 2009. - 256 с

6. Orlov O. Product cost planning / O. Orlov, E. Ryasnykh, K. Larionova // Economy of Ukraine. - 2014. № 12. - P. 39-48.

7. Vasyuk GV Peculiarities of audit of production costs and production costs / G.V. Vasyuk // State and Regions. Series: Economics and Entrepreneurship. - № 4 (67). - 2012. - P. 91.

8. Livoshko TV Planning of measures to reduce the cost of production of an industrial enterprise / T.V. Livoshko, TO Kushnaryova // Economic Bulletin of the Zaporozhye State Engineering Academy. - Zaporizhzhia. - 2014. Vip. 8. S. 28-36.

9. Zaika VV, Vylegzhanina EV Management of prime cost and efficiency of production / In the collection: Actual questions of modern financial science Materials of correspondence all-Russian scientific and practical conference. Kuban State University; Edited by A.V. Пенюгаловой. 2017. S. 113-116.

10. Zhukova EA, Rozhkova MG Problems of cost management in the enterprise // Young scientist. - 2017. № 12. - P. 283-286.

11. Popov LV, Maslov IA Procedure for in-house cost accounting and cost management // Financial Management. 2014.- № 1.- P. 55-57.

12. Budnyak T. Factors for reducing the cost of production / T.I. Budnyak // Theoretical - methodological and scientific "political principles of investment, financial and accounting support of economic development: materials" International. Science. practice. Internetconf. (November 15-16, 2011) PDATU, Kamianets-Podilskyi. - Part 1. Ternopil: Krok, 2011. -372 p.

13. Parfinenko Yu. A. Determination of reserves to reduce costs in order to increase the efficiency of the enterprise / Yu.A. Parfinenko, KI Melnikov // Bulletin of NTU "KhPI". Ser .: Actual problems of management and financial and economic activity of the enterprise. - Kharkiv: NTU “KhPI". - 2013. - № 52 (1025) - P. $124-128$.

14. Sitimov ZR, Ordynskaya ME Calculation policy of the organization // Scientific mechanisms of the decision of problems of innovative development: Collection of articles of the International scientific and practical conference. Part 1. Ufa 2017. P. 124-126. 